\title{
Immunohistochemical Study of Amelogenin and Lysosome- Associate Membrane Proteins (LAMPs) in Cartilage
}

\author{
Estudio Inmunohistoquímico de la Amelogenina y Proteínas de \\ Membrana Asociadas a Lisosomas (LAMPs) en el Cartílago
}

Yuji Hatakeyama*; Junko Hatakeyama**; Kyoko Oka**; Eichi Tsuruga*; Tetsuichiro Inai*; Hisashi Anan"* \& Yoshihiko Sawa*

HATAKEYAMA, Y.; HATAKEYAMA, J.; OKA, K.; TSURUGA, E.; INAI, T.; ANAN, H. \& SAWA, Y. Immunohistochemical study of Amelogenin and Lysosome-associate membrane proteins (LAMPs) in cartilage. Int. J. Morphol., 32(2):618-626, 2014.

SUMMARY: Amelogenin is one of the enamel matrix proteins secreted by ameloblasts during enamel formation in tooth development. Recent studies showed that the amelogenin is expressed in chondrocyte. Lysosome-associated membrane proteins (LAMPs) have been identified as binding partner proteins to amelogenin and it has been suggested they act as signaling receptors of amelogenin. The purpose of this study is to clarify the localization of amelogenin and LAMPs in growth plate cartilage and cartilaginous nodules in micromass culture. Mouse knee joints including tibia growth plate at 4 weeks old and micromass cultures of limb bud mesenchymal cells after 2 weeks were fixed in paraformaldehyde, routinely processed, sections were cut and immunostained with amelogenin, collagen type II and type X, LAMP-1 and -3. The positive immunoreaction of amelogenin was observed both in proliferation and hypertrophic zone cartilage of growth plate after enzymatic pretreatment in immunostaining. Furthermore, cartilaginous nodules in micromass culture were immunopositive to amelogenin. The chondrocytes in the proliferation zone of the growth plate were immunopositive to LAMP-1 but weakly stained in the chondrocytes of hypertrophic zone. These observations indicate that amelogenin may be present in cartilage matrix produced in vivo and in vitro and amelogenin may involve cartilage formation through the LAMP-1 signaling pathway.

KEY WORDS: Amelogenin; Lysosome-associated membrane proteins (LAMPs); Chondrogenesis; Cartilage.

\section{INTRODUCTION}

Amelogenin is one of the enamel matrix proteins secreted by ameloblasts in dental enamel formation. This secreted larger amelogenin is degraded into various smaller amelogenin peptides by proteinases such as matrix metalloproteinase-20 (MMP-20) and kallikrein 4 (KLK4) during enamel mineralization (Haruyama et al., 2010). Organic matrices including amelogenin in enamel are almost totally removed during mineralization of enamel before a tooth eruption. Ameloblasts generate at least 14 mRNA alternative splicing isoforms of amelogenin, and these amelogenin genes and proteins are expressed in the cells forming connective tissues like osteoblasts (Haze et al., 2007), chondrocytes (Haze et al.), odontoblasts (Oida et al., 2002), cementoblasts (Hatakeyama et al., 2003; Nuñez et al., 2010) and periodontal ligament cells (Matsuzawa et al., 2009) in adult tissues.

Furthermore, in vitro assays show that amelogenin induces osteo-chondrogenesis in mesenchyme cells (Veis et al., 2000; Warotayanont et al., 2008; Mitani et al., 2013) and, as we previously reported, the smaller amelogenin peptide promoted chondrogenesis in mouse limb mesenchymal cells (Hatakeyama et al., 2007). These reports indicate that amelogenin may be expressed not only by ameloblasts but also cells derived from mesenchyme cells and may have effects that include signaling molecules in differentiation. However, the distribution in the matrix of connective tissues and the detailed mechanism by which amelogenin induces cell differentiation and mesenchymal tissue formation is still unclear.

Lysosomes are cellular organelles that are involved in endocytosis, phagocytosis or autophagy. For lysosomes function, two classes of proteins are essential: acid hydrolases and lysosomal membrane proteins. The most abundant lysosomal membrane proteins are lysosome-associated membrane protein-1 (LAMP-1, CD107a), LAMP-2 (CD107b), LAMP-3 (CD63). LAMPs are not only present in lysosome membrane but also present in endosomes,

* Section of Functional Structure, Fukuoka Dental College, Fukuoka, Japan.

** Section of Operative Dentistry and Endodontology, Fukuoka Dental College, Fukuoka, Japan.

**** Section of Pediatric Dentistry, Fukuoka Dental College, Fukuoka, Japan. 
phagosomes and cell surfaces (Saftig \& Klumperman, 2009). It has been reported that LAMP-1 located in cell membrane binds to amelogenin and could be a signaling receptor of amelogenin (Tompkins \& Veis, 2006). By using the yeast 2hybrid (Y2H) system it has been identified that LAMP-1 and LAMP-3 are binding partners for mouse amelogenin (Zou et al., 2007). A recent study showed that LAMP-1 can serve as a cell surface binding site for amelogenin on cementoblasts (Zhang et al., 2010). However, the distribution of amelogenin and LAMPs in cartilage and its development is still unknown. To establish the role of amelogenin, in chondrogenesis, we performed an immunohistochemical study of amelogenin, and its binding protein LAMP-1 and LAMP-3 in growth plate cartilage and cartilaginous nodules in micromass culture. We also performed an analysis of the gene profile of LAMPs and chondrogenetic marker genes in micromass culture as a model of chondrogenesis in vivo.

\section{MATERIAL AND METHOD}

Preparation of Tissue Sections. In the present study, C57/ BL6 mice at 4 weeks old were used. All animal studies conformed to guidelines approved by the Animal Experiment Committee of Fukuoka Dental College, Fukuoka, Japan. These mice were anesthetized and perfused with $4 \%$ paraformaldehyde (PFA) in $0.1 \mathrm{M}$ phosphate-buffered saline (PBS), $\mathrm{pH}$ 7.4. After dissection, the knee joints were fixed in $4 \%$ PFA in $0.1 \mathrm{M}$ PBS for $24 \mathrm{~h}$, decalcified in $10 \%$ EDTA and 0.01M PBS (pH7.4) for 4 weeks at $4^{\circ} \mathrm{C}$, dehydrated in a graded series of ethanol, embedded in paraffin, and serially sectioned into coronal sections at $4 \mu \mathrm{m}$ thickness. The sections were stained with hematoxylin and eosin using standard protocols. Serial adjacent sections were provided and immunostained for amelogenin (Amel), collagen type II (Col II), collagen type X (Col X), LAMP-1 and LAMP-3.

Cell culture. Micromass culture of mouse limb bud mesenchymal cells was performed as previously reported with minor modification (Hatakeyama et al., 2004, Zhang et al., 2004). Briefly, timed pregnant C57/BL6 mice were obtained and embryos were collected at embryonic day 10 (E10). Whole limb buds were dissociated into single cell suspension at $1.5 \times 10^{7}$ cells $/ \mathrm{ml}$, plated as $30 \mathrm{ul}$ and cultured in 45\% Dulbecco's Modification Eagle Medium (D-MEM), $45 \%$ F12 Medium, and $10 \%$ fetal calf serum, supplemented with $100 \mathrm{ug} / \mathrm{ml}$ ascorbic acid and $1 \mathrm{mM}$ sodium pyruvate. After 2 weeks culture, cells were fixed with $4 \%$ PFA in $0.1 \mathrm{M}$ PBS for $20 \mathrm{~min}$, removed manually from the cell culture plate and embedded in paraffin and sectioned at $4 \mathrm{~mm}$ thickness. Sections were provided to alcian blue staining and immunostaining to Amel, Col II, Col X, LAMP-1 and LAMP-3.
Alcian blue staining. The presence of sulfated proteoglycans indicative of cartilaginous nodules in micromass culture was detected by alcian blue staining, which was adapted from previous research (Gilbert et al., 2001) with minor modification. Briefly, sections were deparaffined with xylene and rehydrated by decreasing the concentration of alcohol, then immersed in $3 \%$ acetic acid for $3 \mathrm{~min}$. Sections were stained with $0.5 \%$ alcian blue $8 \mathrm{GX}$ in $3 \%$ acetic acid adjusted to $\mathrm{pH} 2.5$ for $30 \mathrm{~min}$ at room temperature. After washing in distilled water, sections were counter stained by Nuclear Fast Red (Kernechtrot) (Sigma, St. Louis, MO, USA) for $5 \mathrm{~min}$ and dehydrated and mounted for observation by light microscopy.

Immunohistochemistry. The primary antibodies used in this study, anti-rat collagen type II (Cosmo Bio/LSL, Tokyo, Japan), anti-rat collagen type X (Cosmo Bio/LSL), rabbit polyclonal to mouse LAMP-1 (Abcam, Cambridge, UK) and rabbit polyclonal to mouse LAMP-3 (CD63 (H-193)) (Santa Cruz Biotechnology, CA, USA) were purchased. Polyclonal anti-bovine amelogenin $\mathrm{C}$-terminus region was kindly provided from Dr. Carolyn W. Gibson, University of Pennsylvania.

For immunostaining of Amel, Col II and Col X, sections were deparaffined with xylene and rehydrated by decreasing concentrations of alcohol. After washing in PBS with $0.05 \%$ Tween 20 , endogenous peroxidase was inhibited for 20 min with $0.3 \% \mathrm{H}_{2} \mathrm{O}_{2}$ in absolute methanol. To retrieve antigen on sections, sections were pretreated with hyaluronidase as described previously (Mizoguchi et al., 1990; Melrose et al., 2003) with minor modifications. Briefly, sections were incubated with $0.025 \mathrm{mg} / \mathrm{ml}$ testicular hyaluronidase (Sigma) in PBS for $90 \mathrm{~min}$ at $37^{\circ} \mathrm{C}$. The sections were washed with PBS three times for $3 \mathrm{~min}$, blocked with $1 \%$ bovine serum albumin in PBS for $20 \mathrm{~min}$, and incubated with each primary antibody, finally diluted 1:200 from original solution of Amel, 1:500 from original solution of $\mathrm{Col} \mathrm{II}$ and $\mathrm{Col} \mathrm{X}$ overnight $(16 \mathrm{~h})$ at $4^{\circ} \mathrm{C}$. After primary antibody incubation, we used biotinylated goat antirat IgG antibody (Vector Laboratories, CA, USA) diluted 1:100 for one hour at room temperature. Binding of the biotinylated secondary antibody to the primary was visualized by peroxidase and 3-Amino-9-Ethylcarbazole (AEC) as chromogen (Zymed Histostain-Plus kits, Invitrogen, Tokyo, Japan). Sections were counterstained with methyl green for $1 \mathrm{~min}$. As a negative control, sections were processed for each sample in the absence of the suitable primary antibody.

For immunostaining of LAMP-1 and LAMP-3, sections were deparaffined with xylene and rehydrated by decreasing concentrations of alcohol. To retrieve antigen on 
sections, sections were treated by $0.01 \mathrm{M}$ sodium citrate buffer, $\mathrm{pH} 6.0$ at $98^{\circ} \mathrm{C}$ for $10 \mathrm{~min}$ and then washed three times for 5 min with PBS. Each primary antibody to rabbit polyclonal to mouse LAMP-1 (Abcam) and rabbit polyclonal to mouse LAMP-3 (CD63 (H-193)) (Santa Cruz Biotechnology) was diluted with PBS at $1 \mathrm{mg} / \mathrm{mL}$, and added to each section. Sections were incubated in the dark overnight $(16 \mathrm{~h})$ at $4{ }^{\circ} \mathrm{C}$ and then washed three times for 3 min with PBS. The immunoreaction was visualized on sections with goat anti-rabbit IgG secondary antibody conjugated to Alexa Fluor 594 (Molecular Probes, Eugene, OR, USA) diluted $10 \mu \mathrm{g} / \mathrm{mL}$ at room temperature for one hour in dark. After washing in PBS, 4', 6-diamidino-2-phenylindole (DAPI) (Vector Laboratories, Burlingame, CA, USA) was used as counterstaining and immediately mounted to observe.

Quantitative Reverse Transcription Polymerase Chain Reaction (real-time quantitative RT-PCR). The gene expression of LAMP-1, LAMP-3 and chondrogenetic differentiation marker genes, Sox9, collagen type II (Col II), collagen type X ( $\mathrm{Col} \mathrm{X})$ and Aggrecan were analyzed by real-time quantitative RT-PCR (MX3005P, Agilent Technologies, Tokyo, Japan). Total RNA was isolated from micromass culture after each culture period, 12, 24, 48, 72 and $96 \mathrm{~h}$ after cell plating initially for $2 \mathrm{~h}$ (Int), using RNeasy Mini Kit (Qiagen, Inc., Tokyo, Japan) according to specifications from the manufacturer. The reverse transcription and real time PCR was performed as previously reported with minor modification (Oka et al, 2007). Briefly, the mRNA was reverse-transcribed into cDNA by using SuperScript ${ }^{\mathrm{TM}}$ First Strand (Invitrogen). The real-time PCR was performed using iTaq ${ }^{\mathrm{TM}}$ SYBR Green Supermix With ROX (Bio-Rad, Tokyo, Japan) for 45 cycles at $95^{\circ} \mathrm{C}$ for 30 seconds, $60^{\circ} \mathrm{C}$ for 45 seconds and $72^{\circ} \mathrm{C}$ for 30 seconds with using each primer designed for chondrogenic differentiation marker gene as previously reported (Hatakeyama et al., 2004). The mouse amelogenin specific primers pairs was used as following: 5'- GGG AGC AGC TTT TGC TAT GC and 5'- GGC TGC CTT ATC ATG CTC TG, which generated a 143-base-pair (bp) amplification product. Melting curve data was collected to check the PCR specificity and the threshold cycle (CT) was defined as the fractional cycle number. Gene expression values are expressed as ratios of differences between the $\mathrm{CT}$ values of interest gene and GAPDH $\left(\mathrm{DCt}=\mathrm{Ct}_{\text {interest }}-\mathrm{Ct}\right.$ GAPDH $)$. By using D(DCt) method, $\{\mathrm{D}(\mathrm{DCt}\}=\mathrm{DCt}$ each culture period $\left.-\mathrm{DCt}_{\text {initial of culture }}\right\}$, the fold change $\left.\left\{2^{-\mathrm{D}(\mathrm{DCt}}\right\}\right\}$ was cultured for each gene. All values are reported as mean \pm SD of the mean for six samples in each group. Cells were plated initially for $2 \mathrm{~h}$, at which time each relative gene expression to GAPDH was designed as $100 \%$. A $P$ value of less than 0.05 was considered statistically significant using Student's t-test.

\section{RESULTS}

In order to identify localization of amelogenin in cartilage, we performed immunostaining of Amel, Col II and $\mathrm{Col} \mathrm{X}$ in growth plate cartilage of 4-week-old mouse tibia. The positive immunoreaction of Col II was observed both in the proliferation and hypertrophic zone cartilage in the section with enzymatic pretreatment (Fig. 1B and F) and the positive immunoreaction of $\mathrm{Col} \mathrm{X}$ was in the hypertrophic cartilage zone (Fig. 1C and G). The positive immunoreaction of Amel was observed both in proliferation and hypertrophic zone cartilage which correlated with expression of Col II (Fig. 1A and E). Chondrocytes in the specific proliferation zone near by hypertrophic zone growth plate cartilage were immunopositive for Amel (Fig. 1E arrow). Chondrocytes in hypertrophic zone were also immunopositive for Amel (Fig. 1E).

To clarify the presence of Amel in the cartilage matrix formed by chondrocyte, we performed immunostaining in cartilaginous nodules formed by chondroblasts differentiated from mesenchyme cells in vitro. After 2 weeks, alcian blue positive cartilaginous nodules (Fig. 3D) were observed in the micromass culture of mouse limb mesenchymal cells. Matrices of these cartilaginous nodules were immunopositive to Col II (Fig. 2C and 2D) and Col X (Fig. 2E and 2F) antibodies. Matrices of these cartilaginous nodules were also immunopositive to Amel antibody (Fig. 2A and 2B) after enzymatic pretreatment, which correlated with the expression patterns of Col II (Fig. 2C and 2D) and Col X (Fig. 2E and 2F).

Then we researched immunolocalization of LAMP1 and LAMP-3, which are suggested amelogenin receptors. In growth plate cartilage of 4-week-old mouse tibia, chondrocytes in the proliferation zone were immunopositive for LAMP-1 (Fig. 3B). However chondrocytes in the hypertrophic zone were very weakly immunopositive for LAMP-1 (Fig. 3B). The immunoreaction of LAMP-3 was weak in chondrocytes both in the proliferation zone and hypertrophic zone (Fig. 3C). In cartilaginous nodules of mouse limb mesenchymal cells, the cells around cartilaginous nodules were immunopositive to LAMP-1 (Fig. $3 \mathrm{E})$ but weak immunopositivity was observed in the cells in matrices (Fig. 3E). The immunoreaction of LAMP-3 was weak in chondrocytes both around and in the cartilaginous nodules (Fig. 3F).

In order to examine the gene profile of LAMPs in chondrogenesis, we performed real time RT-PCR in micromass culture at each culture period, 2 (initial cell 
Amel

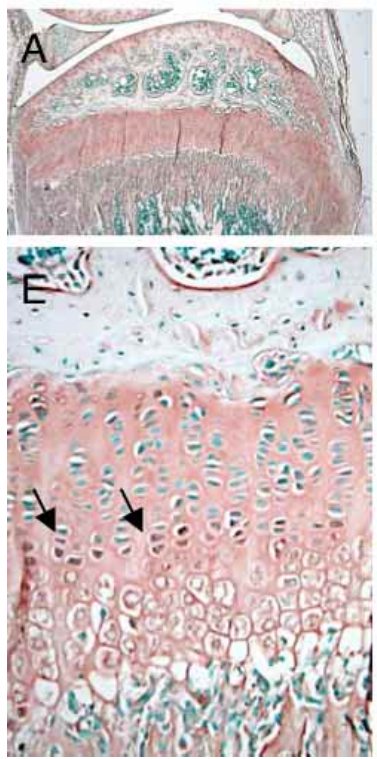

Col II

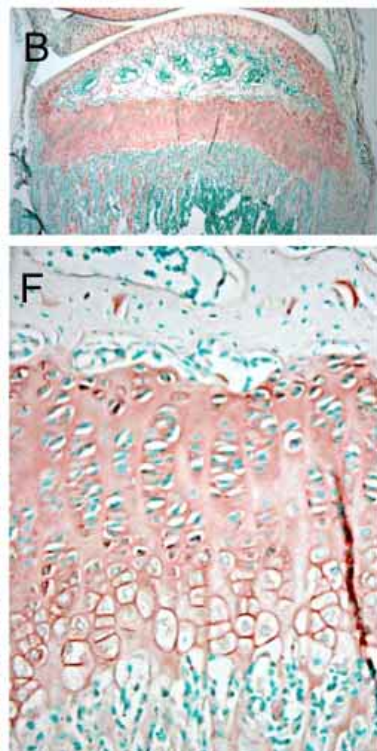

Col X
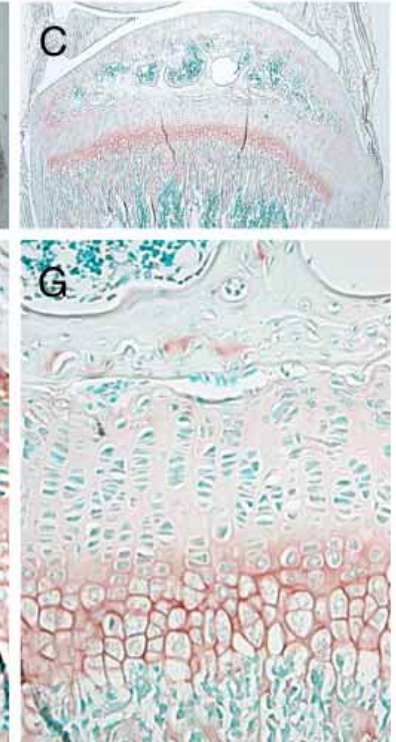

2nd $\mathrm{Ab}$

only

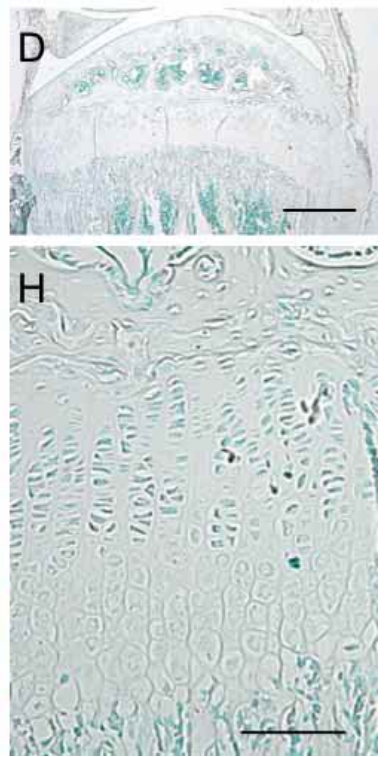

Fig. 1. Immunopositive reaction against amelogenin antibody in growth plate cartilage matrix. 4-week-old mouse tibia was decalcified by $10 \%$ EDTA in $0.1 \mathrm{M}$ PBS and embedded in paraffin. Serial sections were immunostained using amelogenin (Amel, Fig. 1A and E), collagen type II (Col II, Fig. 1B and F) and collagen type X (Col X, Fig. 1C and G). As a negative control, the adjacent serial section was immunostained omitting primary antibodies (2nd Ab only, Fig. 1D and H). Both the proliferation and hypertrophic zone cartilage matrix was stained positive for amelogenin. Chondrocytes in proliferation zone near hypertrophic zone were also positive for amelogenin (Fig.1E, arrow). Scale bar in D for A, B and C images is 500 $\mathrm{mm}$, scale bar in $\mathrm{H}$ for $\mathrm{E}, \mathrm{F}$ and $\mathrm{G}$ images is $100 \mu \mathrm{m}$.

Amel

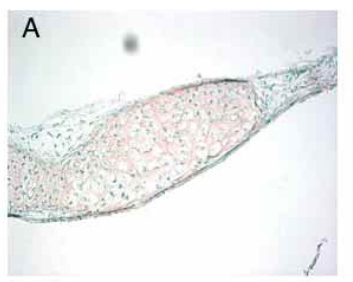

C

Col II
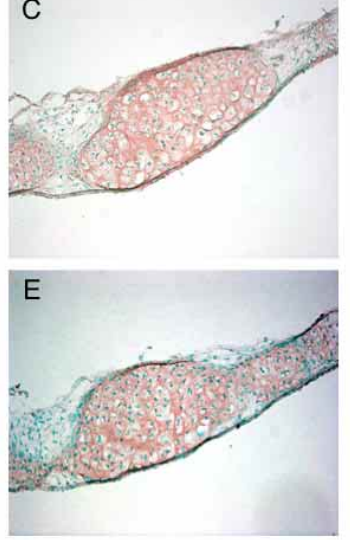

G

$2^{\text {nd }} \mathrm{Ab}$ only
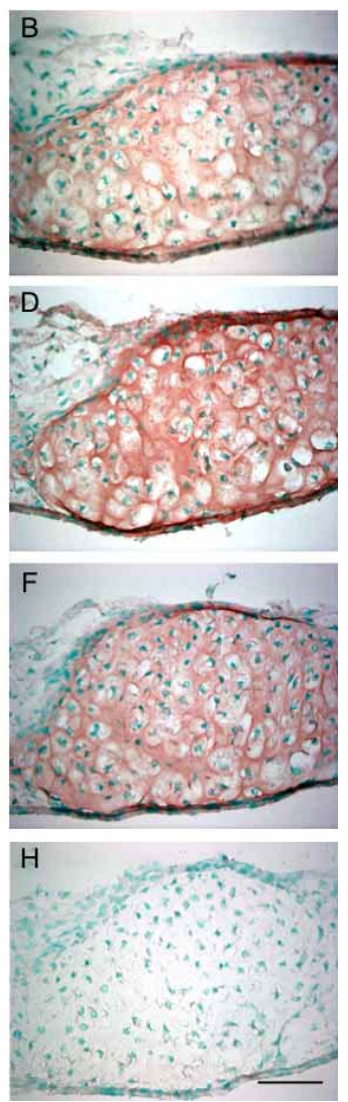

Fig. 2. Immunopositive reaction against amelogenin antibody in cartilaginous nodule formed by mouse limb mesenchyme cell micromass culture. Limb bud mesenchyme cells were cultured for 2 weeks and embedded in paraffin. Serial sections were immunostained using amelogenin (Amel, Fig. 2A and B), collagen type II (Col II, Fig. 2C and D) and collagen type X (Col X, Fig. 2E and F). As a negative control, the adjacent serial section was immunostained omitting primary antibodies (2nd Ab only, Fig. 2G and H). Matrix of cartilaginous nodules was stained positive for amelogenin. Scale bar in G for A, C and E images is 100 $\mu \mathrm{m}$, scale bar in $\mathrm{H}$ for $\mathrm{B}, \mathrm{D}$ and $\mathrm{F}$ images is $50 \mu \mathrm{m}$. 

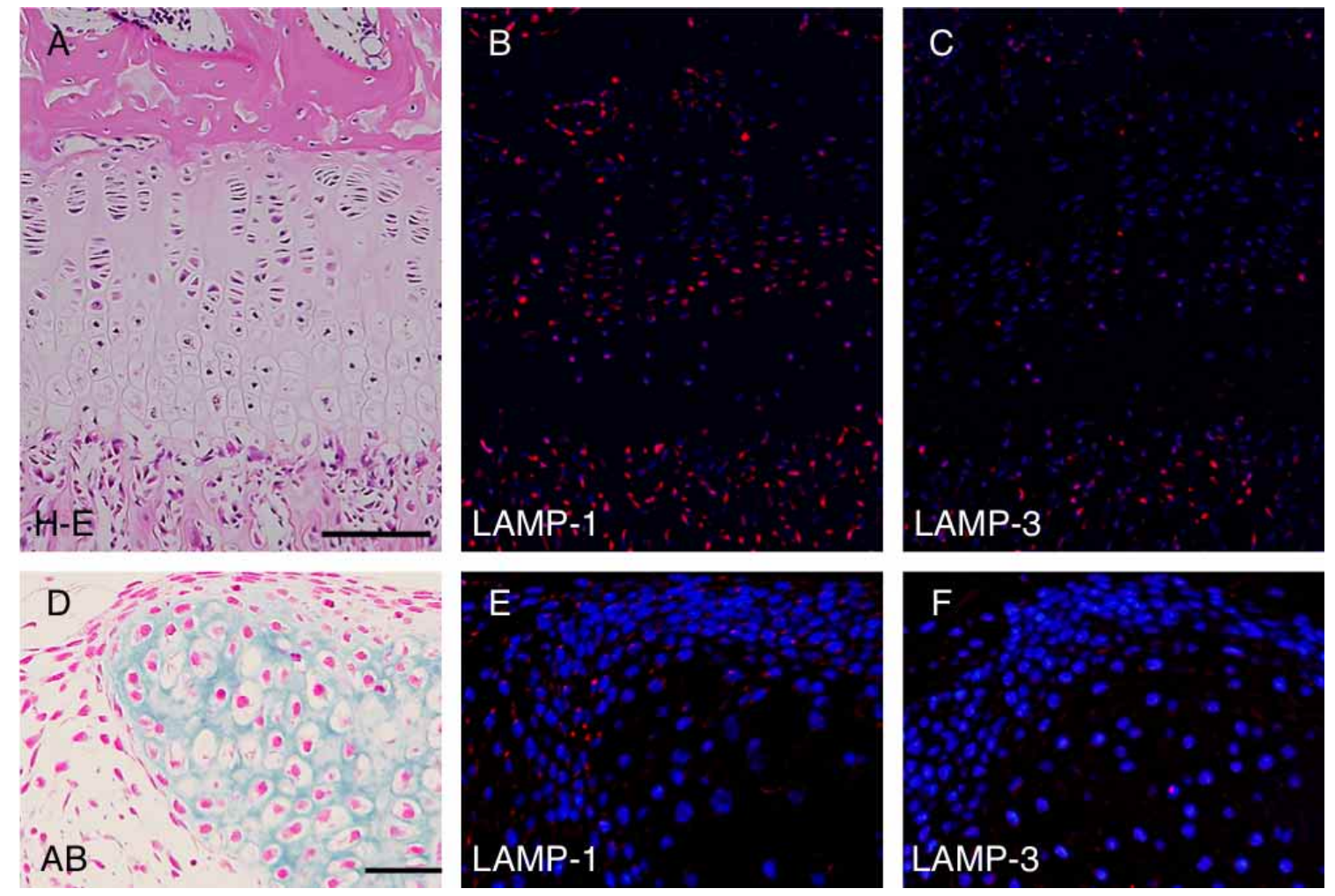

Fig. 3. Immunopositive reaction against LAMP-1 antibody in chondrocyte of growth plate cartilage and cartilaginous nodule. Serial paraffin section of 4-week-old mouse growth plate cartilage of tibia was stained with hematoxylin-eosin (Fig. 3A), and immunostained using LAMP-1 (Fig. 3B) and LAMP-3 antibody (Fig. 3C). Chondrocytes in proliferation zone of growth plate cartilage were stained positive for LAMP-1 but were weakly positive in hypertrophic zone (Fig. 3B). Limb mesenchyme cells were cultured for 2 weeks and serial sections were stained with alcian blue (Fig. 3D), and immunostained using LAMP-1 (Fig. 3E) and LAMP-3 antibody (Fig. 3F). The cells in peri-cartilaginous nodule and chondrocyte were positive for LAMP-1 (Fig. 3E). Chondrocytes both in growth plate cartilage and in cartilaginous nodule were weak positive for LAMP-3 (Fig. 3C and F). Scale bar in A for B and C images is $100 \mu \mathrm{m}$, scale bar in D for $\mathrm{E}$ and $\mathrm{F}$ images is $50 \mu \mathrm{m}$.

plating), 12, 24, 48 and $96 \mathrm{~h}$. The chondrogenic marker genes, Sox9 (Fig. 4A), Col II (Fig. 4B) and Aggrecan (Fig. 4C) were increased after 24-hour culture, and Col X (Fig. 4D) was increased after 48-hour culture compared with initial levels. The gene expression of LAMP-1 was decreased significantly after 48 -hour culture and continued to decrease through to 96-hour (Fig. 4E). However, the gene expression of LAMP-3 was not significantly different compared with initial levels (Fig. 4F). The gene expression of Amelogenin was decreased significantly after $12 \mathrm{~h}$ culture but the gene expression continued to remain through to 96-hour (Fig. 4G).

\section{DISCUSSION}

Amelogenin is one of the enamel matrix proteins produced by ameloblast and it was previously considered an enamel specific protein. However, recent numerous reports indicate the gene and protein of amelogenin is expressed and produced not only in ameloblasts but also cementoblasts (Hatakeyama et al., 2003; Nuñez et al.), and odontoblasts (Oida et al.) involved in tooth formation coordinated with ameloblasts and osteoblasts (Haze et al.). It has been reported that amelogenin protein was found to be expressed in rat and dog articular cartilage chondrocyte (Haze et al.). Our results showed that the matrix of epiphyseal growth plate of mouse is immunopositive for Amel as well as Col II, although we used a different antibody to Amel according to a previous report (Haze et $a l$. .). The specificity of antibody to Amel used in our study was previously shown to reach mouse amelogenin (Gibson et al., 2001). Enzymatic pretreatment in immunostaining targeted for matrices of cartilage is commonly used (Mizoguchi et al.; Wachsmuth et al., 2006). Thus our results suggest that amelogenin protein would be present not only in chondrocyte but also the matrix of cartilage formed in vivo. 
A
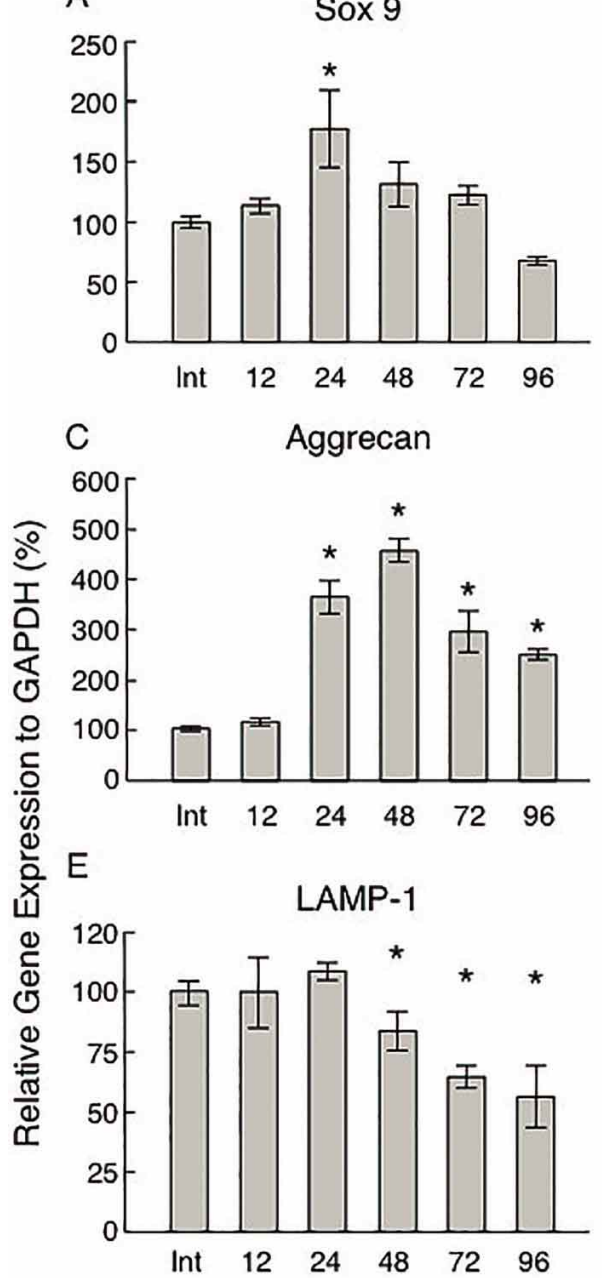

G

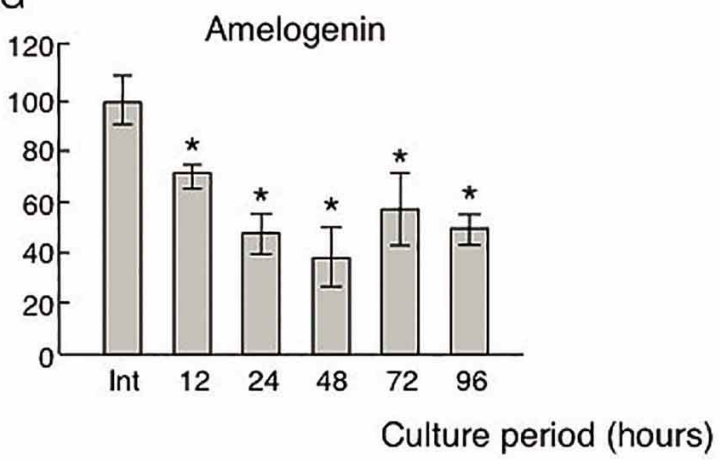

B

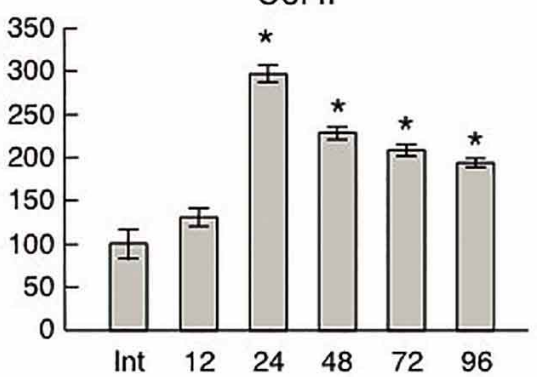

D

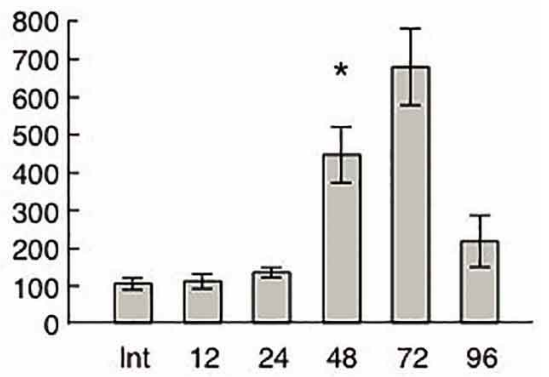

$\mathrm{F}$

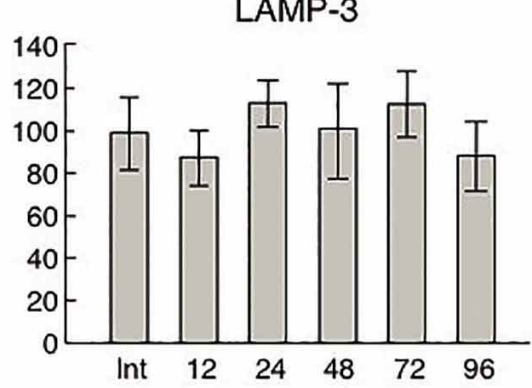

Fig. 4. Gene expression profile of chondrogenetic marker genes and LAMP-1. Total RNA was isolated from micromass culture of mouse limb mesenchyme cultured for $2 \mathrm{~h}$ to $96 \mathrm{~h}$. Realtime RT-PCR was performed on LAMP-1 and each chondrogenetic marker gene, Sox9 (Fig. 4A), collagen type II (Col II, Fig. 4B), Aggrecan (Fig. 4C) and collagen type X (Col X, Fig. 4D). Cells were plated initially for $2 \mathrm{~h}$ (Int), at which each relative gene expression to GAPDH was designed as $100 \%$. The gene expression of LAMP-1 (Fig. 4E) was decreased after $48 \mathrm{~h}$ culture, however that of LAMP-3 (Fig. 4F) for all of the culture period was not significantly different compared with Int. The gene expression of amelogenin (Fig. 4G) was decreased after $12 \mathrm{~h}$ culture and continued to express to $96 \mathrm{~h}$. Data represented mean $+\mathrm{SD}$ of the mean for six samples in each group. $* \mathrm{P}<0.05$ when compared with initial levels. 
Micromass culture was first reported by Ahrens et al. (1977), as a model to study the early sequential events of chondrogenesis and commonly used to examine factors and signaling events involved in chondrogenesis independent of limb development including patterning, outgrowth, digit formation, interdigital apoptosis and jointformation (Capdevila \& Izpisúa Belmonte, 2001). Previous reports have shown micromass culture forwards to chondrocyte maturation and matrix calcification similar to in vivo development (Zhang et al., 2004, DeLise et al., 2000). These studies indicate that matrices of cartilage nodules formed in micromass culture could be similar to matrices of cartilage produced by mesenchymal cell in early chondrogenesis. Thus our results suggest that amelogenin protein may be present in cartilage matrix formed in vitro.

LAMPs are highly glycosylated lysosomal membrane proteins and are associated with vesicular structures of the endosomal system, involving transporting between lysosomes, endosomes and the plasma membrane. The most abundant lysosome membrane proteins are LAMP-1, LAMP-2 and LAMP-3. LAMP-1 and LAMP-2 are highly homologous proteins that overlap normal basic lysosomal functions, although the gene encoding LAMP1 and LAMP-2 are distinct because of their localization on different chromosomes (Saftig \& Klumperman). LAMP-3 was first identified as a human lung specific gene and was suggested to be related to cancer development and/or progression in humans because high gene expression was observed in primary cancers while there was a low level of expression in normal tissues (Ozaki et al., 1998). It has been reported that LAMP-1 has been identified as a cell surface receptor for smaller amelogenin peptides, leucine-rich amelogenin peptides (LRAP) in a mouse fetal myoblast cell line C2C12 (Tompkins et al.).

A recent study has shown that LAMP-1 can serve as a cell surface-binding site for not only for LRAP but also full-length amelogenin on cementoblasts (Zhang et al., 2010). Furthermore LAMP-1 expressed in bone marrow mesenchymal stem cells and full-length amelogenin signaling through LAMP-1 would be involved in mesenchymal cell proliferation through the MAPK-ERK pathway (Huang et al., 2010). Mouse LAMP-3 has also been identified as a binding partner for full-length amelogenin (Zou et al.) with further suggestions that it may be related to amelogenin degradation (Xu et al., 2008).

Our results showed that chondrocytes in the specific proliferation zone near by hypertrophic zone growth plate cartilage were immunopositive for Amel (Fig. 1E arrow). This result is consistent with a previous study, which reports immunopositivity to Amelogenin was observed differentially in specific cell layers of the epiphyseal growth plate (Haze et al.). Furthermore chondrocytes in hypertrophic zone were immunopositive for Amel (Fig.1E). Interestingly, chondrocytes in the proliferation zone were immunopositive to LAMP-1 but were very weak in the hypertrophic zone (Fig. 3B). On the other hand, the immunoreactivity of LAMP-3 antibody was weak in chondrocytes in both the proliferation zone and hypertrophic zone (Fig. 3C). Furthermore, the gene expression of LAMP-1, but not LAMP-3, decreased the maturation of micromass culture involving the increasing of the Col X gene expression (Fig. 4). It has been reported that LRAP induces the chondrogenic and osteogenic gene expression of Cbfa1, Sox 9 and Col II (Veis et al.). Recent our result showed that both full-length amelogenin and LRAP accelerated chondrogenic differentiation and maturation of mouse limb mesenchymal cells and chondrogenic cell lin, ATDC5 (Mitani et al.). Therefore our results suggest the possible role of amelogenin in regulation of cartilage formation through the amelogenin binding protein LAMP-1 does not use LAMP-3 as signaling pathway.

Our study demonstrates the cartilage matrix of growth plate and cartilaginous nodules in micromass culture were immunopositive to Amel antibody after using enzymatic pretreatment, which indicates the amelogenin protein may be present in cartilage matrices produced in vivo and in vitro. Moreover, LAMP-1 may have a role in the signaling pathway for chondrocyte differentiation or chondrogenesis induced by amelogenin expressed in chondrocytes of the proliferation zone. Since it has been reported that the lack of LRAP in non-dental tissues including long bone of Amel null mice may induce smaller body weight than wild type prior to weaning, it has been suggested that amelogenin may be a multifunctional protein during development (Li et al., 2006). However the function of amelogenin in the cartilage matrix is still unknown. Further investigation is necessary to clarify the mechanism of amelogenin in chondrogenesis or homeostasis of cartilage.

\section{ACKNOWLEDGEMENTS}

We thank Carolyn W. Gibson, School of Dental Medicine, University of Pennsylvania, for the gift of the amelogenin antibody. This work was supported by a Grantin-Aid for Scientific Research (C) from the Ministry of Education, Culture, Sports, Science and Technology, Japan, to YH (23592726). 
HATAKEYAMA, Y.; HATAKEYAMA, J.; OKA, K.; TSURUGA, E.; INAI, T.; ANAN, H. \& SAWA, Y. Estudio inmunohistoquímico de la amelogenina y proteínas de membrana asociadas a lisosomas (LAMPs) en el cartílago. Int. J. Morphol., 32(2):618-626, 2014.

RESUMEN: La amelogenina es una de las proteínas de la matriz del esmalte secretadas por ameloblastos durante la formación del esmalte en el desarrollo dentario. Estudios recientes demuestran que la amelogenina se expresa en los condrocitos. Las proteínas de membrana asociadas a lisosomas (LAMPs) se han identificado como proteínas de unión asociadas a la amelogenina; se ha sugerido que actúan como receptores de señalización de la amelogenina. El propósito de este estudio fue aclarar la localización de la amelogenina y las LAMPs en el cartílago de crecimiento y nódulos cartilaginosos en cultivos de micromasa. Articulaciones de la rodilla del ratón, que incluían la placa de crecimiento tibial de 4 semanas de edad y cultivos de micromasa de células mesenquimales del brote del miembro después de 2 semanas se fijaron en paraformaldehído y procesaron rutinariamente. Los cortes fueron sometidos a inmunotinción con amelogenina, colágeno tipo II y X, LAMP-1 y LAMP-3. Se observó inmunorreacción positiva de amelogenina tanto en la zona proliferación e hipertrófica del cartílago de crecimiento después del pretratamiento enzimático. Además, los nódulos cartilaginosos en el cultivo de micromasa eran inmunopositivos para la amelogenina. Los condrocitos en la zona de proliferación de la placa de crecimiento fueron immunopositivos a LAMP-1, mientras que los condrocitos de la zona hipertrófica se tiñeron débilmente. Estas observaciones indican que la amelogenina puede estar presente en la matriz del cartílago producida tanto in vivo e in vitro, además la amelogenina puede estar implicada en la formación de cartílago mediante la vía de señalización de LAMP-1.

PALABRAS CLAVE: Amelogenina; Proteínas de membrana asociadas a lisosomas (LAMPs); condrogénesis; Cartílago.

\section{REFERENCES}

Ahrens, P. B.; Solursh, M. \& Reiter, R. S. Stage-related capacity for limb chondrogenesis in cell culture. Dev. Biol., 60(1):69-82, 1977.

Capdevila, J. \& Izpisúa Belmonte, J. C. Patterning mechanisms controlling vertebrate limb development. Annu. Rev. Cell Dev. Biol., 17:87-132, 2001.

DeLise, A. M.; Stringa, E.; Woodward, W. A.; Mello, M. A. \& Tuan, R. S. Embryonic limb mesenchyme micromass culture as an in vitro model for chondrogenesis and cartilage maturation. Methods Mol. Biol., 137:359-75, 2000 .

Gibson, C. W.; Yuan, Z. A.; Hall, B.; Longenecker, G.; Chen, E.; Thyagarajan, T.; Sreenath, T.; Wright, J. T.; Decker, S.; Piddington, R.; Harrison, G. \& Kulkarni, A. B. Amelogenin-deficient mice display an amelogenesis imperfecta phenotype. J. Biol. Chem., 276(34):31871-5, 2001.

Gilbert, J. A.; Roach, H. I. \& Clarke, N. M. Histological abnormalities of the calcaneum in congenital talipes equinovarus. J. Orthop. Sci., 6(6):519-26, 2001.

Haruyama, N.; Hatakeyama, J.; Hatakeyama, Y.; Gibson, C. W. \& Kulkarni, A. B. Lessons from the Amelogenin Knockout Mice. In: Goldberg, M. (Ed.). Amelogenins: Multifaceted Proteins for Dental \& Bone Formation \& Repair. Paris, Bentham Science Publishers, 2010. pp.25-31.
Hatakeyama, J.; Sreenath, T.; Hatakeyama, Y.; Thyagarajan, T.; Shum, L.; Gibson, C. W.; Wright, J. T. \& Kulkarni, A. B. The receptor activator of nuclear factor-kappa B ligand-mediated osteoclastogenic pathway is elevated in amelogenin-null mice. J. Biol. Chem., 278(37):35743-8, 2003.

Hatakeyama, J.; Hatakeyama, Y.; Haruyama, N.; Takahashi, I.; Kulkarni, A. B. \& Sasano, Y. Amelogenin splicing variant promotes chondrogensis. In: Watanabe, M.; Okuno, O. (Eds.). Interface Oral Health Science 2007. Tokyo, Springer, 2007. pp.193-4.

Hatakeyama, Y.; Tuan, R. S. \& Shum, L. Distinct functions of BMP4 and GDF5 in the regulation of chondrogenesis. J. Cell Biochem., 91(6):1204-17, 2004.

Haze, A.; Taylor, A. L.; Blumenfeld, A.; Rosenfeld, E.; Leiser, Y.; Dafni, L.; Shay, B.; Gruenbaum-Cohen, Y.; Fermon, E.; Haegewald, S.; Bernimoulin, J. P. \& Deutsch, D. Amelogenin expression in long bone and cartilage cells and in bone marrow progenitor cells. Anat. Rec. (Hoboken), 290(5):455-60, 2007.

Huang, Y. C.; Tanimoto, K.; Tanne, Y.; Kamiya, T.; Kunimatsu, R.; Michida, M.; Yoshioka, M.; Yoshimi, Y.; Kato, Y. \& Tanne, K. Effects of human full-length amelogenin on the proliferation of human mesenchymal stem cells derived from bone marrow. Cell Tissue Res., 342(2):205-12, 2010. 
Li, Y.; Yuan, Z. A.; Aragon, M. A.; Kulkarni, A. B \& Gibson, C. W. Comparison of body weight and gene expression in amelogenin null and wild-type mice. Eur. J. Oral Sci., 114(Suppl. 1):1903,2006

Matsuzawa, M.; Sheu, T. J.; Lee, Y. J.; Chen, M.; Li, T. F.; Huang, C. T.; Holz, J. D. \& Puzas, J. E. Putative signaling action of amelogenin utilizes the Wnt/beta-catenin pathway. $J$. Periodontal Res., 44(3):289-96, 2009.

Melrose, J.; Smith, S.; Ghosh, P. \& Whitelock, J. Perlecan, the multidomain heparan sulfate proteoglycan of basement membranes, is also a prominent component of the cartilaginous primordia in the developing human fetal spine. J. Histochem. Cytochem., 51(10):1331-41, 2003.

Mitani, K.; Haruyama, N.; Hatakeyama, J. \& Igarashi, K. Amelogenin splice isoforms stimulate chondrogenic differentiation of ATDC5 cells. Oral Dis., 19(2):169-79, 2013.

Mizoguchi, I.; Nakamura, M.; Takahashi, I.; Kagayama, M. \& Mitani, H. An immunohistochemical study of localization of type I and type II collagens in mandibular condylar cartilage compared with tibial growth plate. Histochemistry, 93(6):593$9,1990$.

Nuñez, J.; Sanz, M.; Hoz-Rodríguez, L.; Zeichner-David, M. \& Arzate, H. Human cementoblasts express enamel-associated molecules in vitro and in vivo. J. Periodontal Res., 45(6):80914, 2010.

Oida, S.; Nagano, T.; Yamakoshi, Y.; Ando, H.; Yamada, M. \& Fukae, M. Amelogenin gene expression in porcine odontoblasts. J. Dent. Res., 81(2):103-8, 2002.

Oka, K.; Oka, S.; Sasaki, T.; Ito, Y.; Bringas, P. Jr.; Nonaka, K. \& Chai, Y. The role of TGF-beta signaling in regulating chondrogenesis and osteogenesis during mandibular development. Dev. Biol., 303(1):391-404, 2007.

Ozaki, K.; Nagata, M.; Suzuki, M.; Fujiwara, T.; Ueda, K.; Miyoshi, Y.; Takahashi, E. \& Nakamura, Y. Isolation and characterization of a novel human lung-specific gene homologous to lysosomal membrane glycoproteins 1 and 2: significantly increased expression in cancers of various tissues. Cancer Res., 58(16):3499-503, 1998.

Saftig, P. \& Klumperman, J. Lysosome biogenesis and lysosomal membrane proteins: trafficking meets function. Nat. Rev. Mol. Cell Biol., 10(9):623-35, 2009.

Tompkins, K.; George, A. \& Veis, A. Characterization of a mouse amelogenin [A-4]/M59 cell surface receptor. Bone, 38(2):17280, 2006.

Veis, A.; Tompkins, K.; Alvares, K.; Wei, K.; Wang, L.; Wang, X. S.; Brownell, A. G.; Jengh, S. M. \& Healy, K. E. Specific amelogenin gene splice products have signaling effects on cells in culture and in implants in vivo. J. Biol. Chem., 275(52):41263-72, 2000.

Wachsmuth, L.; Söder, S.; Fan, Z.; Finger, F. \& Aigner, T. Immunolocalization of matrix proteins in different human cartilage subtypes. Histol. Histopathol., 21(5):477-85, 2006.

Warotayanont, R.; Zhu, D.; Snead, M. L. \& Zhou, Y. Leucine-rich amelogenin peptide induces osteogenesis in mouse embryonic stem cells. Biochem. Biophys. Res. Commun., 367(1):1-6, 2008.

Xu, L.; Harada, H. \& Taniguchi, A. The effects of LAMP1 and LAMP3 on M180 amelogenin uptake, localization and amelogenin mRNA induction by amelogenin protein. $J$. Biochem., 144(4):531-7, 2008.

Zhang, H.; Tompkins, K.; Garrigues, J.; Snead, M. L.; Gibson, C. W. \& Somerman, M. J. Full length amelogenin binds to cell surface LAMP-1 on tooth root/periodontium associated cells. Arch. Oral Biol., 55(6):417-25, 2010.

Zhang, X.; Ziran, N.; Goater, J. J.; Schwarz, E. M.; Puzas, J. E.; Rosier, R. N.; Zuscik, M.; Drissi, H. \& O'Keefe, R. J. Primary murine limb bud mesenchymal cells in long-term culture complete chondrocyte differentiation: TGF-beta delays hypertrophy and PGE2 inhibits terminal differentiation. Bone, 34(5):809$17,2004$.

Zou, Y.; Wang, H.; Shapiro, J. L.; Okamoto, C. T.; Brookes, S. J.; Lyngstadaas, S. P.; Snead, M. L. \& Paine, M. L. Determination of protein regions responsible for interactions of amelogenin with CD63 and LAMP1. Biochem. J., 408(3):347-54, 2007.

Correspondence to:

Yuji Hatakeyama

Department of Morphological Biology

Fukuoka Dental College, 2-15-1 Tamura, Sawara-ku

Fukuoka, 814-0193

JAPAN

Email: hatakeyy@college.fdcnet.ac.jp

Received: 30-03-2014

Accepted: 23-01-2014 